\title{
Atypical citizenship regimes: comparing legal and political conceptualizations
}

Daniel Naujoks (10

Correspondence: daniel.naujoks@ columbia.edu

Columbia University, New York City, USA

\begin{abstract}
Notions, features, and forms of citizenship, understood as legal membership in a state, are changing the world over. While contestations of the monolithic understanding of citizenship generally focus on the content of individuals' rights and their belonging and participation in social and political institutions, this essay shows that official membership categories that are labeled 'citizenship' by state actors vary. Drawing on the experiences of the Overseas Citizenship of India, the British Overseas Citizenship, and Citizenship of the European Union the essay proposes an analytical framework that aims at advancing the comparative study of state membership policies by introducing six key dimensions that policy actors consider when designing citizenship policies. Apart from systematizing the content of citizenship, the framework sheds light on the importance of citizenship terminology, as states employ the label of citizenship and use the status as a vehicle of communication. The essay highlights differences in the construction of special subjects, moral obligations and the exercise of power, analyzes the aspirations of political actors, the political rhetoric, and explores the interplay between tangible rights and intangible narratives. The discussion of the three atypical membership regimes reveals that states operate in grey areas of membership statuses that partly mimic existing forms of state membership and partly push the boundaries of what state membership means. This has significant repercussions for comparative citizenship and democracy theory and the meaning of membership.
\end{abstract}

Keywords: Citizenship, Naturalisation, European Union, European citizenship, Overseas Citizenship, India

\section{Introduction}

Notions, features, and forms of citizenship, understood as legal membership in a state, are changing in many regions of the world. Despite these changes a monolithic and homogenous understanding of what citizenship means prevails in much of the discussions on state membership. Contesting the standard view, Hammar (1990) introduced denizenship to describe the citizenship-like status of long-term residents, as did several authors with an emphasis on quasi-citizenship (Groenendijk, 2006; Smith, 2017). For others, quasi-citizenship refers to certain expansions of rights regimes for diaspora and ethnic populations that mimic the content of citizenship policies without conferring the citizenship label (Knott, 2017; Yasar, 2017). Cohen's (2009) semicitizenship assesses the rights of individuals as a gradient category, that is not

(c) The Author(s). 2019 Open Access This article is distributed under the terms of the Creative Commons Attribution 4.0 International License (http://creativecommons.org/licenses/by/4.0/), which permits unrestricted use, distribution, and reproduction in any medium, provided you give appropriate credit to the original author(s) and the source, provide a link to the Creative Commons license, and indicate if changes were made. 
necessarily linked to formal citizenship status. ${ }^{1}$ In addition, Soysal (1994) explored postnational citizenship to understand how regimes beyond the nation state have influenced individual rights in nation states. Pedroza (2019) further reminds us that even core citizenship rights, such as the right to vote, can be detached from formal citizenship status.

It is useful to recall that scholars use different conceptions of citizenship. In particular, they may focus on citizenship as a legal status; a system of rights; a form of political activity; and a form of identity and solidarity (Bosniak, 2000). While contestations of the monolithic understanding of citizenship generally focus on the content of rights and duties of individuals and their belonging and participation in social and political institutions, this essay shows that citizenship as a legal status, that is, official membership categories that are labeled citizenship by state actors, vary. $^{2}$ The analysis adds to assessments of extra-territorial citizenship that are found to differ from full citizenship rights (Barry, 2006), which led Fitzgerald (2008) to the description of "citizenship à la carte."

The study of atypical citizenship regimes focuses on three cases where the label is present--but not the full status and extent of core rights--, namely the Overseas Citizenship of India, British Overseas Citizenship, and Citizenship of the European Union. These regimes have been established for different reasons: diaspora and emigrant engagement in India, addressing the repercussions of the British Empire, and creating a supranational organization in the case of the EU. This essay highlights differences in the construction of special subjects, moral obligations, and the exercise of power. It analyzes the aspirations of political actors, the political rhetoric, and explores the interplay between tangible rights and intangible narratives.

The conceptualizations draw on in-depth content analysis of parliamentary debates in India and the U.K., as well as EU policy-making processes. ${ }^{3}$ This essay aims beyond highlighting the objective differences in the policy design of atypical membership policies. By examining the policy-making processes, the expressed expectations, and the official implementation of the legal regimes the analysis contributes to a more nuanced understanding of how states create citizenship regimes. It highlights the dialectic of using established forms and terms and reinterpreting the concepts, which, in turn, has an impact on the underlying notions.

Consequently, the essay offers three key contributions to discussions on comparative citizenship studies. First, the proposed analytical framework aims at advancing the

\footnotetext{
${ }^{1}$ Cohen (2009) establishes different categories of semicitizenship based on the strength of two types of rights individuals have: autonomous rights, which are valuable regardless of context and relative rights that take meaning from their specific political context. She observes different forms of semicitizenship for LGBT citizens; felons; children; cultural minorities; non-citizens; and undocumented persons.

${ }^{2}$ For an overview of citizenship related questions, see Aleinikoff and Klusmeyer (2002); Bauböck (2017); Bloemraad and Sheares (2017); Shachar, Bauböck, Bloemraad, and Vink (2017). According to Bloemraad and Sheares (2017) citizenship is a specific legal status "that signals a relationship between an individual and a sovereign state" (824). Though they acknowledge that "nation-states' centrality does not mean scholars should ignore substate or supra-state membership." (827) It shall be noted that not only are the historic origins of the citizenship concept much older than the modern state system, some constitutions still denote membership in territorial polities more generally, including those at sub-state level. This is the case in the US, but also in Switzerland and Austria, leading to multilevel structure of territorially nested citizenships (Maas, 2017).

${ }^{3}$ Records of the discussions on all three membership regimes are accessible online, see https://www. parliament.uk; https://parliamentofindia.nic.in and https://europa.eu.
} 
comparative analysis of state membership policies by introducing six key dimensions that policy actors consider when designing citizenship policies. Apart from systematizing the content of citizenship, the framework sheds light on the importance of citizenship terminology, as states employ the 'label' of citizenship and use the status as a vehicle of communication. The essay shows that while atypical forms of citizenship may initially by viewed as merely symbolic and ornamental, they regularly develop into categories with concrete impacts. From this I develop the seed function of atypical citizenship regimes.

Second, while scholars have examined the developments of EU citizenship, ${ }^{4}$ Overseas Citizenship of India and British Overseas Citizenship have not yet attracted much scholarly analysis. ${ }^{5}$ In addition to introducing a range of novel insights into these forms of membership, this essay's third contribution lies in advancing our conceptual understanding of citizenship regimes. From a detailed comparison of these three forms of citizenship that have been adopted at different times, by different actors, and serve different purposes, we learn about the processes through which states creatively establish new forms of membership. As atypical citizenship regimes need discursive and normative justification, the related discourse reveals many of the implicitly understood meanings of state membership, advancing our understanding of the contours of citizenship in general.

\section{Selecting citizenship regimes}

The forms of citizenship compared in this analysis have been chosen to represent a high degree of conceptual diversity while all operate under a state membership framework and the official label 'citizenship.'

Overseas Citizenship of India (OCI) is the quintessential form of a diaspora membership policy. In 2003, legislation on OCI was adopted to avoid providing full dual citizenship with an innovative status that still employs the citizenship label. ${ }^{6}$ The scheme became operational in 2006, and by the end of 2017, almost 3.2 million persons of Indian origin had obtained OCI. ${ }^{7}$ Other membership policies that emulate certain elements of citizenship include special ethnic-status 'cards' like the Turkish Pink (and later Blue) Card, the Ethiopian Origin Identity Card, or the Hungarian Ethnic Identity Card, as well as nationality schemes without political rights. ${ }^{8}$ While other statuses established for diaspora populations resemble OCI, they often are not officially framed as citizenship or nationality regimes.

The British Overseas Citizenship (BOC) represents the re-interpretation of membership in the U.K. as a former empire and a post-colonial alignment of population classifications with recognized categories of nation states. BOC was introduced by the British Nationality Act (BNA), 1981 alongside two other forms of citizenship, namely the British Citizenship and the British Overseas Dependency Citizenship.

\footnotetext{
${ }^{4}$ For an overview of debates on EU citizenship, see Maas (2007, 2017), and Kochenov (2013).

${ }^{5}$ Notable exceptions include Naujoks (2013, 2015); Sahni (2009); Sarhadi Raj (2015); Xavier (2011) on OCI and Hansen (2000) on BOC.

${ }^{6}$ In 1999, the Indian government had launched the Person of Indian Origin Card (PIO card). The scheme was revised in 2002 and terminated in 2015, granting all previous holders OCI.

${ }^{7}$ For more information on the development of OCI issuances, see Naujoks (2013, pp. 62-5).

${ }^{8}$ Barry (2006) and Fitzgerald (2006) discuss key characteristics of external citizenship regimes. See Knott (2017) and Yasar (2017) for additional examples of semi-citizenship.

${ }^{9}$ See Hansen (2000) for the processes that led to the BNA 1981.
} 
Differentiating between different categories of people that previously held the common 'citizenship of the U.K. and Colonies' (CUKC). The main thrust of the BNA 1981 was to define British citizenship and to distinguish it from the other two labels. ${ }^{9}$ To understand the principal objectives of the reform, it is necessary to highlight the genesis of British citizenship concepts. Before 1949, there were only British subjects, comprising everybody who owed allegiance to the British Monarch, and British Protected Persons whom the British had granted protection. As Canada created its own citizenship in 1946 and India and Pakistan gained independence in 1947, the U.K. created the citizenship of the U.K. and Colonies (CUKC). This was an extremely wide category that in 1977 included some 950 million people in all major regions of the world. ${ }^{10}$ Already before the BNA 1981 came into force, many citizens, that is, CUKCs, were barred from entering the U.K. The anomaly in Britain's citizenship conception was that through the Commonwealth Immigrants Acts 1962 and 1968, and the 1971 Immigration Act, Commonwealth passport holders and CUKCs were subject to immigration control unless they, their parents or grandparents or-for women - their husband had been born, adopted, naturalized or registered in the U.K. This status of being 'connected to the United Kingdom and Islands' was referred to as patrial. Thus, of the 950 million British subjects and CUKCs only a few enjoyed any significant rights toward the U.K. The basic idea behind the BNA 1981 was to provide new labels for existing de facto categories. Indeed, very few changes in the rights, access, and other dimensions of British citizenship were part of this legislative project. The 1981 Act formalized this relationship by naming those who had the right of abode in the U.K. British citizens, those who had the right of abode in dependent territories British citizens thereof and all the rest with no tangible rights or privileges British overseas citizens. In addition, BOC was the ideational precursor of the $\mathrm{OCI}$, as the Indian government copied BOC's legal provisions to create OCI. As the objective of OCI is fundamentally different from that of BOC, the comparison of these two statuses makes distinctions in the discussions and conceptualizations particularly interesting.

EU citizenship captures the aspirations of supranational entities to replicate nation-state institutions. The 1991 Maastricht Treaty established that every person holding the nationality of a member state of the European Union is automatically at the same time a citizen of the Union. ${ }^{11}$ Since 1982, the Economic Community of West African States has a protocol in place that defines 'community citizens.' While the protocol aims at creating common principles on citizenship, it leaves discretion to its member states. Similar statuses are under discussion at the Union of South American Nations (Acosta Arcarazo, 2015), the Andean Community, and the Association of Southeast Asian Nations. However, the evolution of EU citizenship can also be contrasted with areas of free mobility that lack an explicit citizenship dimension, such as the Nordic Passport Union that was created in 1952 (Turack, 1968). As the most developed form of supranational citizenship, EU citizenship remains the most critical point of reference for regional membership regimes. In addition to differences in the objective and context of these statuses, only EU citizenship creates a multilevel structure of territorially nested citizenships

\footnotetext{
${ }^{10}$ Edward Gardner, House of Commons, 28 January 1981.

${ }^{11} \mathrm{EU}$ citizenship underwent only minor changes by amendments during the following intergovernmental conferences (Maas, 2017).
} 
(Maas, 2017), OCI requires a primary citizenship from another country, and among the three statuses, only BOC can be the sole state-status that a person may have.

While the three cases are not exhaustive conceptualizations of atypical forms of citizenship, they allow for an in-depth comparison of how membership categories are conceived in three different scenarios. The historic, conceptual, and functional differences of the three regimes allow us to draw more generalized conclusions about how states construct official membership categories.

\section{Analytical framework: six policy dimensions of constructing citizenship}

Both in the academic use and in actual state practice, there are several meanings of citizenship and if and how it is different from nationality. Here, I will use the term 'citizenship' and not 'nationality' to denote an individual's legal membership in a state. Several scholars have advanced our understanding of different dimensions of citizenship. For example, Carens (2000) differentiates the legal (formal rights and duties that one possesses as a member of a political community), psychological (a sense of identification with the political community) and political (one's sense of representational legitimacy of those who act authoritatively on behalf of and in the name of the political community) dimensions (p. 162). Faist, Gerdes, and Rieple (2004) state that citizenship "essentially comprises three mutually qualifying dimensions: first and foremost, the notion of collective selfdetermination and democracy; second, the legally guaranteed status of equal political freedom and other rights; and third, membership in a political community" (p. 917). They further distinguish between the intrastate and interstate function of nationality, depending on whether we focus on defining the rights and duties of citizens or the relationship between citizens and the outside, at times hostile, world. Bauböck (2005) explains key elements of citizenship policies, such as control over the acquisition of nationality, territorial jurisdiction over foreign nationals, control over their own external citizens living abroad, as well as core privileges that generally attached to citizenship status, namely, the franchise in general elections, the unconditional right of residence and diplomatic protection (pp. 6-8).

This essay follows an inductive approach that derives the concept of citizenship not from theoretical reasoning but from a comparison of actual citizenship practices. Taking inspiration from the above conceptualizations but principally based on the analysis of the three examined citizenship regimes, I develop a framework that distinguishes six dimensions of citizenship from the state and policy perspective (Fig. 1). It takes citizenship as a legal status as the starting point and uses the dimensions to meaningfully discuss key features of establishing citizenship policies.

States can grant a status and create a state label (label and status dimension), they may (and generally will) substantiate the status with concrete and special rights and often also duties (privilege dimension), they may grant status holders certain powers to change the rules of the polity, most importantly by providing for political participation (political dimension). Further, the state has to consider the importance of this status for status-holders when they are outside of the country's territory, i.e., vis-à-vis other countries (external dimension). 


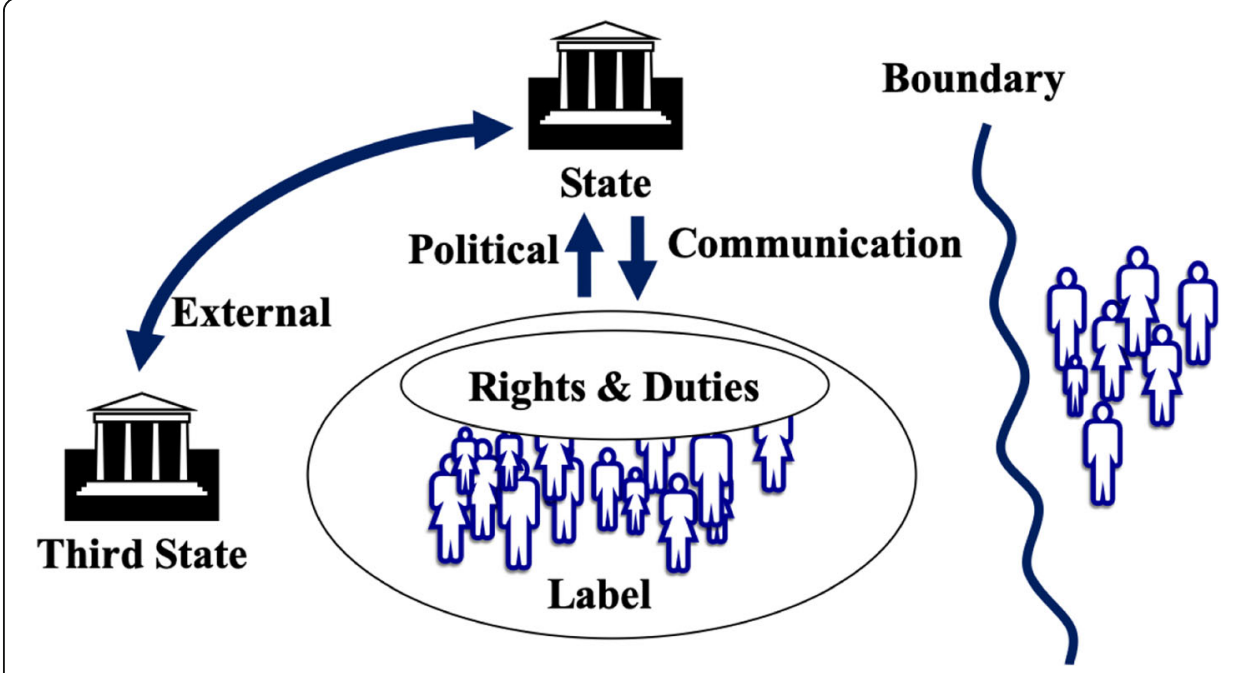

Fig. 1 Dimensions of Citizenship Policies from the State Perspective

While the above dimensions describe the content of citizenship, the fifth dimensions concerns access to citizenship, i.e., the modes of its acquisition and loss and the definition, who is a citizen and who is not (boundary dimension). The last dimension looks at the use of the status as a rhetoric tool in states' communication strategy (communication dimension). For the sake of clarity, there are important individual dimensions of citizenship that are not dealt with directly here. These include how citizenship is experienced, how granted privileges and participatory powers are used, how emotional attachment to the political community is constructed and what it means to feel allegiance to a political community. ${ }^{12}$ In the remainder of this essay, I will elaborate on each dimension of the regimes in turn.

The label and status dimension

All citizenship regimes start with a label. The official name attached to a person or a group of persons that implies the relationship between this group of people and a state. This name generally refers to a legal status as a conglomerate of rights and duties between the state and the individual. The status dimension of citizenship policies is often not explicitly addressed. Citizenship as a status means that a special membership concept is adopted with a name that evokes certain expectations about citizenship and nationality.

Most of the rights and characteristics associated with EU citizenship were already partially outlined by the 1957 Treaty of Rome and the Single European Act, especially the freedom of movement, which has been expanded and complemented by the jurisprudence of the European Court of Justice (Closa, 1992; Maas, 2007). Thus, the idea of citizenship was superimposed over a range of pre-existing privileges. Closa (1992) finds that the introduction of Union citizenship introduced for the first time "a systematic concept of

\footnotetext{
${ }^{12}$ Thränhardt (2008) discusses the identity and instrumental use of citizenship for naturalizing individuals and Bloemraad and Sheares (2017) elaborate on why citizenship status matters (or not).
} 
citizenship in the Community ambit" (p. 1137). More than the rights itself it offers a systematization of such rights, centered on the common label citizenship.

Also the Indian case illustrates the importance of the status dimension. In 1999, the Indian government had introduced the PIO Card, which provided many essential privileges, such as the right to stay indefinitely in the country (during the 20year validity of the card, which later got reduced to 15 years). In addition, there are several special rights that allow persons of Indian origin without any particular status to buy real property and invest into companies. ${ }^{13}$ However, the government's High-level Committee on the Indian Diaspora (2002) found that many overseas Indians were keen on dual nationality because "they considered a legislative provision of dual nationality a higher form of the acknowledgement of their linkage with Mother India" (p. 526). Thus, independent from the benefits or privileges granted, the special status of 'citizenship' matters. In this regard, OCI is similar to EU citizenship as an attempt to superimpose a label over existing rights.

Let us now turn to the status dimension of British Overseas Citizenship (BOC). Carens (2000) argues that in the conventional understanding of citizenship there is a tight fit between the legal and the psychological dimension (p. 166). The lack of this 'tight fit' for many citizens of the U.K. and colonies seemed the starting point for BOC. The British government explained that BOC "represents the relationship with the United Kingdom held by people connected with countries which were once part of the British Empire; or whose ancestral connections with the United Kingdom or its present dependencies are not sufficiently close to qualify them for British Citizenship or Citizenship of the British Dependent Territories" (U.K. Home Office, 1980, p. 20). However, despite lacking the quality to be labeled British citizens, these people were still provided with a status. Statements such as "Any CUKC would acquire one of the three citizenships. None of them would be excluded" are mentioned frequently in the government's 1980 White Paper and throughout the parliamentary debate on the BNA 1981. This appears to reflect the U.K.'s international obligation to avoid statelessness and to not withdraw its citizenship status from certain individuals and groups. Because they had a status that sounded like citizenship, they needed a status that resembled citizenship, at least at the nominal level.

\section{The privilege dimension}

Privileges and claims are critical because without them it becomes fuzzy what membership in a state means. The privilege dimension is particularly important for atypical forms of citizenship-but not only. ${ }^{14}$ While there is a general idea what 'ordinary full national citizenship' is, this is less the case for these special statuses. Thus, to give meaning to the label special rights have to be associated with it.

As argued above, the initial rights associated with EU citizenship existed before the creation of this special legal status. However, their association with EU citizenship was sought in order to fill the new status with rights and hence meaning. ${ }^{15}$ These are in particular the right to move and reside freely within the territory of the member states, political rights and consular protection, discussed

\footnotetext{
${ }^{13}$ Naujoks (2018) discusses economic rights granted to persons of Indian origin that are unrelated to OCI.

${ }^{14}$ Joppke (2010, p. 13) shows how political forces attempted to strengthen the meaning of British citizenship by tying more benefits to formal citizenship than to legal resident status, taking away rights from the latter.

${ }^{15}$ Fundamental rights are seen as the key dimension of EU citizenship (Brink, 2019; Kochenov, 2013).
} 
in the following sections. The European Commission stresses that European citizenship can make European citizens' sense of belonging to the European Union more tangible by conferring on them the rights associated with it. ${ }^{16}$ The expected effect of such conferment of rights is reflected in several policy statements. For instance, the Austrian delegation found that the specific rights associated with citizenship were "not substantive enough and the concept as such has not been successfully implanted in the collective consciousness". ${ }^{17}$

OCI grants its holder certain privileges, such as the right to enter the country and work there. Although OCI is introduced in the Citizenship Act, the act does not enumerate the rights of overseas citizens. Whereas restrictions on political rights, government positions, and government employment are regulated by law, the benefits of OCI are exclusively given through government notifications. The major right is 'parity with Non-resident Indian citizens (NRIs)', i.e., full Indian citizens who reside abroad. Since the launch of Overseas Citizenship in 2006, the Indian government has announced some 'additional benefits' during its annual diaspora conference, including parity with NRIs in the matter of inter-country adoption of Indian children, domestic airfares, and admittance into national parks. The principal aim of these privileges lies not in the rights themselves but in the desire to fill the status of OCI with meaning.

From the start, the reform of British citizenship law in the late 1970s leading to the BNA 1981 did not want to change any privileges for the re-labeled individuals. This is particularly the case with regard to the right to reside in the U.K. One of the principal reasons for Britain's citizenship reform was that the CUKC "does not identify those who belong to this country and have the right to enter and live here freely; in consequence it prevents the United Kingdom from basing its immigration policies on citizenship" (U.K. Home Office, 1977, p. 4). Especially since "In most Western countries, citizens-and citizens only-automatically have that right." (U.K. Home Office, 1977, p. 9). Thus, already the 1977 Green Paper made clear that BOC "would not carry with it the right of entry to the [U.K.]" (U.K. Home Office, 1977, p. 6). Hence, the new categorization perpetuated the unique situation that somebody would be a nominal citizen of a country but not have the right to enter it. Another privilege associated with $\mathrm{BOC}$ is diplomatic protection to which I will come back when discussing the external dimension.

It was feared that by introducing British overseas citizenship, the U.K. would "be setting different standards of citizenship" 18 and fail to bring "together status on the one hand and rights and duties on the other." ${ }^{19}$ Parliamentarians remarked that it "seems to confer no right of abode and a passport that is almost meaningless". ${ }^{20}$ This lack of rights led to questioning the citizenship itself, as "British overseas citizenship [ ... ] will not be a true nationality at all. [ ... ] It confers no rights on the holder, except the right to apply for a passport. [ ... ] even those who apply successfully will get passports that admit them to the land of nowhere."

\footnotetext{
${ }^{16}$ European Commission, Report on the operation of the TFEU, quoted in European Parliament (1997).

${ }^{17}$ 'Fundamental positions of Austria for the Intergovernmental Conference,' quoted in European Parliament (1997).

${ }^{18}$ Sydney Bidwell, House of Commons, 28 January 1981.

${ }^{19} \mathrm{~J}$. Enoch Powell, House of Commons, 28 January 1981.

${ }^{20}$ Arthur Davidson, House of Commons, 30 July 1980.

${ }^{21}$ Victor Mishcon, House of Lords, 22 June 1981.
} 
An element that appears to be of relevance when designing citizenship policies is the idea of duties. All three atypical forms of citizenship assessed here contain references to certain duties while this dimension seems rather meaningless for all concepts. The Treaty of the Functioning of the EU regulates that citizens of the Union shall be subject to the duties imposed by the Treaty, without elaborating what duties these might be. The British Government expressed its concern "that the creation of rights would eventually lead to pressure for reciprocal duties. [ ... ] National citizenship can involve obligations of military service, and nation states impose duties of taxation. The EU, however, is not a state, and should take care not to develop ideas which feeds people's fear that it has a vocation to become one." ${ }^{22}$ When member states voted in April 1996 on whether certain obligations, such as a Euro humanitarian service, should be added to the Treaty, only Greece and France voted in favor, while Germany, Spain, and Sweden signaled an uncertain or negotiable position and all other member states abstained.

Similar to full citizens, BOCs have to pledge that they "will be faithful and bear true allegiance to" the queen. In his citizenship review for the British Prime Minister, Goldsmith (2008) justifies this by declaring that the "reciprocal link between protection and allegiance is shown in the form of the oath and pledge taken by those who acquire British citizenship or one of the forms of British nationality" (38). In the first draft of India's Citizenship (Amendment) Bill, 2003, overseas citizens were required to solemnly affirm or swear that they will "bear true faith and allegiance to the Constitution of India as by law established, and that [they] will faithfully observe the laws of India and fulfill [their] duties as an overseas citizen of India." However, within the legislative proceedings, this provision was deleted because it was held that "the allegiance to the Constitution cannot be divided and it would create problems with their primary citizenship" (Standing Committee on Home Affairs, 2003, para. 7.6.2).

\section{Political dimension}

Political rights are often regarded as the "defining and primordial element of citizenship [ ...] In domestic law, the term 'citizen' applies only to persons in possession of full political rights." (Closa, 1992, p. 1139, emphasis in the original) However, it is important to bear in mind that non-democratic states do not provide such powers to their citizens while the formal concept of citizenship as state membership remains unchallenged by the lack of democratic rights. At different points in time, female citizens did not have equal voting rights, and neither did descendants of African slaves in the United States and convicted felons and prisoners are often excluded from political rights (Cohen, 2009). Classifying state members without political rights as subjects and only those with political powers as citizens may be a relevant terminological differentiation for political philosophy, but it seems less important from the perspective of legal state membership and its discursive conceptualizations.

The disassociation between citizenship and its political dimension is a remarkable feature of the British debate, not only for the residual category of BOC but also for full

${ }^{22}$ U.K. White Paper, "A partnership of Nations. The British Approach to the European Union IGC 1996". March 1996. 
British citizenship. From the start of the discussion in 1977, the Labour and Tory governments made clear that there is no clear connection between voting rights-referred to as civic rights-and citizenship.

"What we want is citizenship [ ... ]. However, civic privileges are a separate matter. [ ... ] Civic rights are not part of nationality law. [ ... ] it is not the case that nationality by itself, basically important as it is, is connected with civic rights. The State has the right to give civic rights to whom it likes." ${ }^{23}$

The following government repeated this standpoint in the debate explicating that "The proposals for nationality do not impinge on voting rights. [ ... ] because voting rights arise from the Representation of the People Act. [ ... ] they are genuinely separate." 24

Also OCI does not entail any political rights. In fact, the Indian Citizenship Act explicitly bars OCIs from any active or passive political participation. Not giving OCIs political rights seemed to be a consequence of India's reluctance to give its citizens overseas in general political power, as well as of the intended auxiliary nature of the status. When OCI was adopted, Indian citizens living abroad had no voting rights. This changed when in September 2010, the Indian parliament passed the Representation of the People (Amendment) Act, 2010, providing non-resident Indian citizens the right to register their names in the electoral roll and to vote in Indian elections provided that they come to India on the polling day. OCIs continue to be without voting rights and the Indian political system seems unlikely to provide such rights. This is also connected to the policy-makers' idea that OCIs would live permanently abroad and only occasionally come to India. In this case, democracy theory has emphasized that it may correspond to democratic ideals to exclude expatriate citizens from voting rights (Bauböck, 2005; Spiro, 2016).

There are several political rights that are associated with EU citizenship. Most importantly, Union citizens have the right to vote and to stand as candidates in elections to the European Parliament and in municipal elections in their member state of residence. Further, they have the right to petition the European Parliament, to apply to the European Ombudsman, and to address the institutions and advisory bodies of the Union in any of the Treaty languages and to obtain a reply in the same language. Further in 2007, the Lisbon Treaty introduced a new form of public participation for European citizens, the Citizens' Initiative, which allows one million citizens who are nationals of a significant number of EU countries to call directly on the European Commission to bring forward an initiative of interest to them within the framework of its powers.

\section{The external dimension}

In the classic conception of citizenship (or nationality) and under public international law, the state is responsible for its citizens, it has to accept them into its territory and

\footnotetext{
${ }^{23}$ Secretary of State for the Home Department, Merlyn Rees, House of Commons, 27 April 1977.

${ }^{24}$ Secretary of State for the Home Department, William Whitelaw, House of Commons of 30 July 1980. But also see Pedroza (2019)'s analysis of immigrant voting rights without formal citizenship status around the world.
} 
can claim diplomatic protection if their rights are violated and make claims on their behalf. Nationals travel on the basis of a travel-document that is tied to their nationality, i.e., a passport, and the country's standing and agreements with other countries chiefly determines the ease or difficulty of entering other countries with that passport. When in distress, nationals residing abroad have regularly the right to seek help from the consular representation. ${ }^{25}$ The interstate function of nationality includes the right "to protect the citizens of a state against the outside, at times hostile, world" (Faist et al., 2004, p. 917).

This interstate function is almost completely absent from OCI, since it does not delineate OCI card-holders as Indian citizens to third countries and it is not geared toward their protection abroad. With the OCI certificate, they cannot travel to other countries, and even to enter India, they need their primary non-Indian passport in addition to their OCI booklet. ${ }^{26} \mathrm{OCI}$ was the attempt to create a status that included diasporic Indians into the Indian state without creating confusion about their status toward their country of residence. Former Indian Prime Minister I.K. Gujaral confirms the policy that is known as 'Nehru doctrine,' that "We never encourage our people abroad to have dual loyalty. The loyalty must remain with the country of adoption. [...] The idea that we encouraged basically was, that wherever an Indian is living, then he must be looked at as one of them. And we have never encouraged a duality of loyalty, because dual loyalties create problems for them." ${ }^{27}$

In the first drafts of the Maastricht Treaty, citizens of the Union were entitled to the protection of all member states in any third country (Closa, 1992, p. 1164). In the final text, however, this right would be subject to the principle of subsidiary representation, that is, if the country of nationality does not have a representation in the country in which the person requires assistance. ${ }^{28}$

Introducing the British Government's Green Paper on the citizenship reform in 1977, the Secretary of State for the Home Department, Merlyn Rees, underscored that CUKC as a nationality concept has not been accepted in Europe because "it is not citizenship in the sense of the term accepted elsewhere. [ ... ] the final concept should mean that a British citizen, once given that classification, should have the right to free movement in Europe" ${ }^{29}$ While this statement refers to British Citizenship and not to BOC, it is clear that the recognition of the status by third countries is of seminal importance. But also BOC has importance in the external dimension. Indeed, one could argue that BOC is hardly anything but an external label with close to no internal content. For overseas citizens who would not have another citizenship, the government proclaimed that British Overseas citizens are entitled to diplomatic protection by the British government "in the same way as any other British national", and would be eligible to hold a U.K. passport

\footnotetext{
${ }^{25}$ Under public international law, the right to claim diplomatic protection is a right of the state, whose national is in distress. However, under domestic law, the individual may have a claim vis-à-vis her government.

${ }^{26}$ Until January 2015, OCIs also needed a U-visa in their primary passport that was connected to their OCI status.

${ }^{27}$ Interview with the author on 5 June 2008. For the Nehru doctrine, see Dubey (2003).

${ }^{28}$ The European Parliament states that the concept or status of citizen implies that vis-à-vis third countries, citizens must be accorded full protection by the community as a whole. See, European Parliament resolution on Union citizenship, 14 June 1991, A3-0139/91,

${ }^{29}$ House of Commons, 27 April 1977.
} 
describing their citizenship (U.K. Home Office, 1980, pp. 20-1). It may be doubted that the U.K. could actually exercise the proclaimed diplomatic protection, whereby a state is entitled to protect its subjects against acts contrary to international law committed by another state. The International Court of Justice decided that, in addition to the formal citizenship status, this requires a genuine connection with that state. ${ }^{30}$ While it could be questionable whether BOC is 'citizenship' in terms of public international law, BOCs' genuine connection with the U.K. could be ever more doubtful.

\section{Boundary dimension}

A key element of any citizenship policy is to determine who will obtain such a status. This refers to the question of the transitional and permanent rules for citizenship acquisition, as well as the loss of the status. Transitional rules determine the eligible persons and the modes of acquisition at the time of the introduction of the citizenship status, while permanent rules regulate on a permanent basis, who (may) acquire citizenship status and how. The boundaries of citizenship are determined simultaneously by democratic and liberal norms as well as administrative rationality (Cohen, 2009, Ch. 4).

For full citizenship, case-to-case acquisition is the exception. The vast majority of citizenship acquisitions happen ex lege and automatically either by being born in the country (ius soli) or by descent (ius sanguinis). Cases of individual acquisition through naturalization or registration are much rarer. For example, in the U.S., only 21 out of 299 million citizens, or $7 \%$, are naturalized citizens, while the remaining 93\% are native-born citizens (2017 American Community Survey). Drawing the boundaries of membership statuses is connected to normative questions of exclusion and inclusion and to what degree polities can decide what groups will benefit from the newly created status and what populations may not. In order to understand the discussions and policy-making processes, it is important to know what groups were targeted by the respective policy changes. Beyond abstract discussions on the statuses, characteristics of the affected populations are key to a deeper comprehension of inclusionary and exclusionary tendencies.

In January 1983, all former CUKCs, who did not fall under the other two categories, acquired automatically overseas citizenship. This applied predominantly to persons of Indian origin, living in Malaysia, Kenya, and India. The British government estimated their numbers 1.5 million, admitting though that no reliable system existed for a count. About 200,000 of them were expected to have no other citizenship. ${ }^{31}$ Thus, BOC was conferred automatically by law. As a special status, it did not provide the possibility to 'opt in.' In addition, status holders were generally barred from transmitting the status to the next generation because allowing "people with these distant connections to pass on citizenship further" would be "contrary to the general principles [of...] the new Act" (U.K. Home Office, 1980, p. 20). However, the law allowed minors to register, on a continuous basis, for BOC

\footnotetext{
${ }^{30}$ International Court of Justice, Nottebohm Decision (Liechtenstein v. Guatemala) in: ICJ Report 23 (1955), p.23.

${ }^{31}$ Victor Mishcon, House of Lords, 22 June 1981. Mishcon explains further that "those in India are, almost all of them, persons originating from East Africa who went under pressure to India after they had lost their right of entry to the [U.K.]." See also Fransman (1998, p. 276).
} 
at the discretion of the Secretary of State. In addition, certain persons would automatically become BOCs if they otherwise became stateless.

India's political history has caused technical difficulties in drawing the legal contours of who should be eligible for OCI. People had left colonial India in the 19th and twentieth century for all continents. Upon independence in 1947, British India was divided into Hindu-majority India and Muslim-majority Pakistan while, in 1971, East Pakistan split from the western part of the country to form modern-day Bangladesh. Hence, the population of Pakistan and Bangladesh is 'of Indian descent' when the concept is looked at from the perspective of the undivided, pre1947 India. The uneasy fit of the sizeable pre-independence diaspora into membership schemes in the Republic of India is thus reflected in the definitions of eligible persons. ${ }^{32}$

In the beginning, the OCI scheme was supposed to be restricted to a few countries only. The original Bill as introduced into the Parliament in 2003 contained a list of eight countries to whose citizens of Indian origin OCI could be granted. ${ }^{33}$ The Parliament's Standing Committee on Home Affairs included eight more countries. ${ }^{34}$ This was based on four reasons. First, it was argued that diaspora communities' demand for 'dual citizenship' was limited to these countries. Second, national laws in several other countries, for instance South Africa, La Reunion, and Guadeloupe, would not allow for such a status. The third reason for this limitation lies in the general security concerns held by India's security agencies, including the Ministry of Home Affairs. Then Home Minister L.K. Advani stated that the selection of countries was driven by "our thinking about our national security." 35 A fourth factor can be seen in the attempt to provide specific incentives for diaspora actors in affluent countries, whose role for India's economic development was assessed particularly significant. In 2005, the scope of OCI was extended to citizens of all countries except Pakistan and Bangladesh.

EU citizenship follows automatically from official citizenship status in one of the EU member states. It cannot be acquired directly, and it is not open to anybody who is not a national of one of the member states. The Court of Justice of the European Union (CJEU) had a critical role to flesh out the boundary dimension, when it comes to member state competence to determine who is a Union citizen. In Micheletti (1992), the CJEU forced member states to recognize other member states' attribution of citizenship and in Rottmann (2010), it introduced legal standards for member states' power to deprive their nationals of EU citizenship (van Eijken, 2010). ${ }^{36}$ It is argued that the greatest inadequacy of European citizenship is its failure to address the situation of the millions of third country nationals permanently residing in the EU. Leaving the important normative question aside to what extent these third country nationals should have been included, from the genesis of Union citizenship it appears, that their exclusion was not an objective of the project. Governments' main challenge was to create a status that would

\footnotetext{
${ }^{32}$ For an in-depth discussion of the eligibility criteria for OCI, see Naujoks (2013, pp. 57-62).

${ }^{33}$ Those were Australia, Canada, Finland, Ireland, Italy, Netherlands, U.K., and the U.S.

${ }^{34}$ Namely, Switzerland, Greece, Israel, Sweden, France, Cyprus, Portugal, and New Zealand.

${ }^{35}$ Home Minister L.K. Advani, as quoted in Naujoks (2015, p. 25).

${ }^{36}$ See CJEU, Case C-369/90 Mario Vicente Micheletti and others v Delegación del Gobierno en Cantabria [1992] ECR I-04239; and case C-135/08, Janko Rottmann v Freistaat Bayern.
} 
resemble national citizenship and that would bring 'the EU closer to its citizens'. This policy nonetheless raises the question how much exclusion needs citizenship as a policy of integration and to what extent can this be a rhetorical exclusion and to what extent has it to be a substantial one.

\section{Communication dimension}

What citizenship means is largely constructed in social discourse. And this discourse is shaped by official communication about citizenship and the symbolic value attributed to it. For this reason, it is important to assess the usage and attributed meaning in the official language used on government websites, in reports, brochures, and speeches. The communication dimension is in many ways related to the (hoped-for) psychological effects of citizenship. Several scholars have explained the means used by states, governments, and political leaders to use symbols, ideologies, and stories of peoplehood (Smith, 2003) to constitute political identities and attachments. ${ }^{37}$ The right communication strategy-it is hoped-will help to foster a common 'national identity', a sense of belonging and attachment. Governments' starting point is the conventional understanding of citizenship. In fact, they use the term 'citizenship' because they want to allude to and play with the conventional understanding that 'the man or woman on the street' has. In this dimension, state actors use the citizenship label and the associated rights for political rhetoric and employ rituals, such as ceremonies and oaths, to shape the targeted populations. It is important to note that the intended audience of certain communication endeavors may vary. With regard to discussions on restricting access to citizenship and rights of non-citizens in the U.K., Joppke (2010) argues that "the function of citizenship talk is less to be found in its illocutionary purpose of integrating newcomers than in its perlocutionary effect of pacifying ill-disposed natives" (p. 14).

The government of India's communication strategy shows interesting variations over time and is characterized by a high 'PR factor' of OCI. Since the 1980s, India's diaspora relations have witnessed a major policy paradigm shift, which I have dubbed as 'from the invisible diaspora to the diaspora empire' and 'from the traitor tune to a pride paradigm' (Naujoks, 2010). However, can a diaspora-friendly rhetoric work without conferring rights? Or to what extent does the home country have to grant rights and privileges in order to appear as a credible, committed partner in the joint diaspora-homeland venture? As actions speak louder than words, there was the need to manifest the declared paradigm shift with concrete policy outcomes. Barry (2006) finds that a metaphoric or rhetorical strengthening of membership is not sufficient in all cases to respond to emigrant claims for more institutionalized inclusion into the national polity (p. 59).

OCI is framed as a message that India listens to the diaspora's demands, acknowledges their contributions, and recognizes their dual status. In this way,

\footnotetext{
37 For an overview, see Gordon (2007, pp. 368-9).

${ }^{38}$ Signalling theory in economics and human resources is based on the idea that one party (termed the agent, here the government) credibly conveys some information about itself to another party (the principal, here the target audience of the communication) (Connelly, Certo, Ireland, \& Reutzel, 2011).
} 
citizenship policies have what economists call a signaling function. ${ }^{38}$ With regard to full dual citizenship, India seems to have found a feasible way to counter the existing claims by referring to the fact that this is not allowed by the Indian Constitution. This argument is generally accepted, despite the fact that it is legally not convincing ${ }^{39}$ and considering that the constitution could be amended, as it has been done in several other countries (Jones-Correa, 2001). In addition to constitutional inadmissibility, reasons of national security given by the political system as further objections to full dual citizenship are also widely accepted. ${ }^{40}$ The acceptance of these reasons is easier because the general communication strategy from the political system has overcome the traitor tune and is now a matter of pride.

European institutions use the concept of citizenship in their direct communication and attempt to rally people around a common label. For instance, the European Commission regularly drafts reports on EU citizenship and the year 2013 has been declared the European Year of Citizens with opportunities to learn about the rights and opportunities open to them thanks to EU citizenship. ${ }^{41}$ In fact, Weiler (1996) referred to European Citizenship as a "cynical exercise in public relations" (p. 68).

An important communication feature of citizenship policies lies in the status function described above. State entities find it easier to refer to a general status and exemplify its meaning by referring to specific rights than advertise the rights themselves. In fact, in 1993, the European Commission stated that the right of residence for community nationals is governed by ten Council directives and regulations adopted between 1968 and 1990 and by a 1970 Commission regulation. Thus, it appeared more feasible to communicate about one status that encompasses several rights than referring to a host of rules and regulations. This was also the case with OCI and the regulations for investment and economic activities. While other regulations and norms often provide the real privileges, OCI and EU citizenship are convenient 'flat rate policy vehicles' to communicate these benefits.

The British government did not use BOC to communicate with the 'target population,' i.e. potential BOCs. This is not surprising since the status was rather negatively connotated and did not lend itself to a positively framed PR outreach. In this way, the communication function is absent from the status. However, the government used the creation of the status to communicate internationally to fence off accusations that U.K. decolonization policies were producing stateless people. This serves as a reminder that communication endeavors can have multiple audiences.

\section{The seed and shell function of citizenship}

From a cynical perspective, the label-dimension of citizenship appears to be nothing but a psychological trick to manipulate citizens' sense of belonging, increase governability, and ease the exercise of power. However, the label and status function matters as the seed for future expansions.

First, it increases people's activities to mobilize around certain institutions and labels such as citizenship. This is an empirical, not a normative statement. Second, it

\footnotetext{
${ }^{39}$ See High-level Committee on the Indian Diaspora (2002, Chapter 36); Naujoks (2013, p. 299).

${ }^{40}$ For security-related narratives in the policy-making process of OCI, see Naujoks (2015).

${ }^{41} \mathrm{See}$, EU online presentation, archived at www.webcitation.org/69eBePOr6.
} 
creates scope for changes and additional rights that may be added later by political institutions. Third, the idea that citizenship is more than the sum of its individual rights leads courts and non-political institutions to the creation of new rights and to the expansion of others. Thus, the idea of membership and full membership that is inherent in the common understanding of the term 'citizenship' can lead to developments that were initially not foreseen. How much control parliaments and governments keep over the status depends on the social and legal context and the strength of institutions.

Already the 1991 Spanish proposal emphasizes that the "concept and content of [European] citizenship are conceived of as having an evolving dimension". Thus, the Spanish proposal included an article that would give the European Council the right "to add rights and obligations over and above those laid down in the Treaty". This provision is similar to the granting of such a right to the Indian government for OCI. While this clause never got incorporated in the EU treaty, many observers have stressed the dynamic nature of the concept. Closa (1992) concludes that EU citizenship has "above all" provided a solid basis for further enlargements of the rights attached to citizenship (1168). Delanty (2007) calls it a "putative European citizenship" and O'Keefe (1994) assesses that its importance lies not in its content but rather in the promise it holds out for the future. The existence of the citizenship label combined with the idea of full membership led to attempts to adding new privileges during each revision of the EU treaty. Other institutions, in particular the European Court of Justice and the Commission have enlarged the meaning and importance of the concept (van Eijken, 2010; Wiener, 2011). Yakut (2010) shows that the court has moved from a market interpretation of understanding citizenship as an economic citizenship to a more substantive, political citizenship concept. As legal scholars find, having a separate chapter and provisions indicates that citizenship has not only declaratory character (Closa, 1992; Yakut, 2010).

The Immigration Law Practitioners' Association (ILPA, 2001) claims that "No one should be without the right of abode in the country of their nationality. Every British national should have a right of abode in the U.K." Consequently, the ILPA urges the British government to " $[\mathrm{u}]$ pgrade all living British passport holders to British Citizens with right of abode in the U.K., by registration by entitlement". Indeed, two important changes occurred. First, the British Overseas Territories Act 2002 granted the right of abode in the U.K. to those formerly known as British Dependent Territories citizens. Second, the Nationality, Immigration, and Asylum Act 2002 allowed British Overseas Citizens, British Subjects, and British Protected Persons who have no other nationality to register as British citizens and hence acquire the right to enter and live in the U.K. If BOCs had not been granted their nominal status, which-as discussed above-gave them virtually no rights or privileges, then they would not have benefitted from the change of law in 2002, which made it easier for some of them to become British citizens. In his review of citizenship at the request by the British Prime Minister, Goldsmith (2008) suggests abolishing the residual categories of citizenship-including BOC-and providing the

${ }^{42}$ Goldsmith (2008) explains, "Though this change will only affect relatively small numbers of people, it is important to address the history involved in the residual categories as part of renewing our common bond of citizenship" (p. 6). 
Table 1 Citizenship Dimensions for Atypical Membership Policies

\begin{tabular}{|c|c|c|c|c|}
\hline \multicolumn{2}{|l|}{ Dimension } & EU Citizenship & $\begin{array}{c}\text { British Overseas } \\
\text { Citizenship (BOC) }\end{array}$ & $\begin{array}{c}\text { Overseas Citizenship } \\
\text { of India (OCI) }\end{array}$ \\
\hline \multicolumn{2}{|l|}{ Label } & - & - & - \\
\hline \multicolumn{2}{|l|}{ Privilege } & $\bullet$ & & - \\
\hline \multicolumn{2}{|l|}{ Political } & $\bullet$ & & \\
\hline \multicolumn{2}{|l|}{ External } & - & - & \\
\hline \multirow[t]{2}{*}{ Boundary } & Inclusion & $\begin{array}{l}\text { Formal citizens of } \\
\text { EU member states }\end{array}$ & $\begin{array}{l}\text { CUKCs, who were not } \\
\text { eligible for full British } \\
\text { Citizenship or citizenship } \\
\text { of the British Dependent } \\
\text { Territories (mostly } \\
\text { persons of Indian origin, } \\
\text { who migrated at the time } \\
\text { of the British Empire to } \\
\text { Malaysia and Kenya). }\end{array}$ & $\begin{array}{l}\text { Overseas Indians, } \\
\text { especially those in } \\
\text { OECD countries }\end{array}$ \\
\hline & Exclusion & $\begin{array}{l}\text { As corollary: Third- } \\
\text { country nationals } \\
\text { residing in EU }\end{array}$ & $\begin{array}{l}\text { The residual category of } \\
\text { BOC aims at excluding } \\
\text { certain former British } \\
\text { subjects from British } \\
\text { Citizenship and } \\
\text { Citizenship of the British } \\
\text { Dependent Territories. }\end{array}$ & $\begin{array}{l}\text { Citizens of Pakistan and } \\
\text { Bangladesh. Informally } \\
\text { also Indian diaspora } \\
\text { communities whose ties } \\
\text { are more distant. }\end{array}$ \\
\hline \multicolumn{2}{|c|}{ Communication } & - & & - \\
\hline
\end{tabular}

Note: indicates the relevance of a dimension for the respective citizenship policy.

-indicates the relevance of a dimension for the respective citizenship policy

concerned individuals access to full British citizenship. ${ }^{42}$ Thus, an inherent feature of such statuses is what one may want to call the 'seed function' of citizenship. Even though the rights may be extremely limited at a certain point in time, the fact that such a status exists carries the potential for greater privileges in the future. This may be connected to administrative logics of having created an official category of persons, as well as inherent normative ideas of what citizenship means. Thus, a status may be regarded an empty shell. But it is easier to fill an empty shell than to create a new one. The mere fact that a status exists and that our conventional understanding associates it with tangible benefits, leads to its expansion.

\section{Concluding remarks}

Table 1 provides an overview of the different citizenship dimensions for the three atypical membership statuses examined here. While the main thrust of these dimensions lies not in a binary 'yes/no' distinction, the above explorations show that BOC and OCI omit several elements that are normally associated with state citizenship regimes. The analysis of the policy-making and implementation processes shows that in addition to objective construct deviations, the underlying rationales and policy expectations have to be incorporated into a comprehensive theory of formal state membership.

It could be argued that atypical membership policies that are labeled as 'citizenship' are designed to (fraudulently) use the commonly accepted meaning of citizenship, while in reality they cannot be classified as citizenship policies, as they lack fundamental attributes. In fact, some observers are interested in judging whether 
these concepts are indeed forms of citizenship. This, of course, involves a firm idea of what citizenship is. Since OCI is confined to market exchange and "divorced from the 'political' and 'social' limbs of the trio of citizenship rights", Sahni (2009) classifies the status as economic citizenship (5), Xavier (2011) refers to the concept sui generis (pp. 44-6). and Sarhadi Raj (2015) as rhetorical citizenship (165). As quoted above, when British overseas citizenship was introduced it was feared that the U.K. would "be setting different standards of citizenship." ${ }^{43}$ Thus, the classic text on British nationality law states that "It would be more apt to call [BOC] a status [... ] than a citizenship" (Fransman, 1998, p. 279).

Reviewing atypical forms of citizenship, it is interesting to note the tension between accepted concepts of what citizenship means, on the one hand, and the need to tailor membership policies to specific needs, on the other. This reminds us that too often we might have a too firm and fixed concept of what citizenship and membership in a country mean and that there are atypical citizenship forms that capture some of the traditional elements while abandoning others. And there is no consensus about a minimum threshold to consider a status citizenship.

One reason why questions related to citizenship often appear either too easy to answer from a formalistic point of view or to fuzzy from a more substantial angle is that the meaning of citizenship is constructed by social discourse. The socially-constructed idea about community and citizenry underpins the belief of many that being a citizen is more than having the right to vote and the duty to defend the country--to name citizens' arguably best-known right and duty. Asking for the meaning of OCI, it is not enough to look at the privileges granted. We must also look at the social meaning that is attributed to it through the official language used by government institutions, administrative practices, assessments by diasporic actors, and depictions in the mainstream discourse, especially in the press. Importantly, as long as an official status contains the word 'citizenship' in its name, the discourse has a tendency to reflect this name and construct a citizenship meaning around the concept. For this reason, nomenclature matters. ${ }^{44}$

While there is no major wave to reinvent state citizenship newer statuses continue to contest the concept's homogenous notion. Extra-territorial and diaspora citizenship provides a lasting challenge to the ongoing territorial bias in citizenship studies and to territorial understandings of state sovereignty (Collyer, 2017). The analysis here has shown that a comprehensive theory of citizenship has to overcome the rigid dichotomy between citizens and non-citizens by incorporating certain in-betweens. States often operate in grey areas of membership statuses that partly mimic existing forms and partly push the boundary of what state membership means. This requires a differentiated approach to assess the interlinkages between state and group membership, legal status, and the varied inclusion of groups into polities.

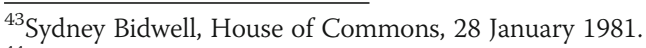

${ }^{44}$ In a qualitative study of diasporic Indians in the U.S. and U.S.-returned migrants in India, most participants recognized at a rational level that OCI is less than full dual citizenship. Nonetheless, when not asked "what is OCI?", they refer to it as dual citizenship and it generally fulfils the function of dual citizenship, although not always and not for everybody (Naujoks, 2013, pp. 215-23).
} 


\section{Abbreviations}

BNA: British Nationality Act; BOC: British Overseas Citizenship; CUKC: Citizenship of the U.K. and Colonies'; OCl: Overseas Citizenship of India

\section{Acknowledgements}

I thank Dietrich Thränhardt for inspiring the research that led to this comparison of atypical forms of citizenship. I am grateful to Willem Maas, Saeed Khan, Olivier Vonk, and Costica Dumbrava for having shared their thoughtful comments on an earlier draft. This essay also benefitted from insightful observations at the American Political Science Association annual meeting and the Citizenship Studies Conference at the Center for the Study of Citizenship, Wayne State University, as well as helpful suggestions by three anonymous reviewers.

\section{Authors' contributions}

I am the sole author and hence solely contributed to the manuscript. The author read and approved the final manuscript.

\section{Funding}

No funding was received for this study.

\section{Availability of data and materials}

Data sharing not applicable to this article as no datasets were generated or analysed during the current study.

\section{Competing interests}

The author declares that he has no competing interests.

Received: 6 November 2018 Accepted: 23 September 2019

Published online: 13 January 2020

\section{References}

Acosta Arcarazo, D. (2015). Toward a south American citizenship? The development of a new post-national form of membership in the region. Columbia Journal of International Affairs, 68(2), 213-221.

Aleinikoff, T. A., \& Klusmeyer, D. (Eds.) (2002). Citizenship policies for an age of migration. Washington, DC: Carnegie Endowment for International Peace and Migration Policy Institute.

Barry, K. (2006). Home and away: The construction of citizenship in an emigration context. (New York University Public law and legal theory, Working Paper No. 23). New York University School of Law. Retrieved from https://pdfs.semanticscholar. org/9c17/96866353943772e07774fbaf595bffca1a9d.pdf.

Bauböck, R. (2005). Citizenship policies: International, state, migrant and democratic perspectives. Global migration perspectives 19. Geneva: Global Commission on International Migration. Retrieved from https://www.refworld.org/docid/42ce4dd54. html.

Bauböck, R. (2017). Political boundaries and democratic membership. In A. Shachar, R. Bauböck, I. Bloemraad, \& M. Vink (Eds.), The Oxford handbook of citizenship, (pp. 60-82). Oxford: Oxford University Press.

Bloemraad, I., \& Sheares, A. (2017). Understanding membership in a world of global migration: (how) does citizenship matter? International Migration Review, 51(4), 823-867.

Bosniak, L. S. (2000). The state of citizenship: Citizenship denationalized. Indiana Journal of Global Legal Studies, 7(2), 447-510.

Brink, M. (2019). EU citizenship and (fundamental) rights: Empirical, normative, and conceptual problems. European Law Journal, 25(1), 21-36.

Carens, J. (2000). Culture, Citizenship, and Community: A Contextual Exploration of Justice as Evenhandedness. New York: Oxford University Press.

Closa, C. (1992). The concept of citizenship in the treaty on European Union. Common Market Law Review, 29, 1137-1169.

Cohen, E. F. (2009). Semi-citizenship in democratic politics. New York and Cambridge: Cambridge University Press.

Collyer, M. (2017). Diasporas and transnational citizenship. In A. Shachar, R. Bauböck, I. Bloemraad, \& M. Vink (Eds.), The Oxford handbook of citizenship, (pp. 576-598). Oxford: Oxford University Press.

Connelly, B. L., Certo, S. T., Ireland, R. D., \& Reutzel, C. R. (2011). Signaling theory: A review and assessment. Journal of Management, 37(1), 39-67.

Delanty, G. (2007). European Citizenship: A Critical Assessment. Citizenship Studies 11 (1), 63-72

Dubey, A. (2003). Indian diaspora in the Caribbean and Africa: Identity issues and responses of India. In idem (Ed.), Indian Diaspora. Global Identity, (pp. 117-145). New Delhi: GOPIO international, Kalinga publications.

European Parliament. (1997, February 20). Intergovernmental conference (Briefing No. 10). European Citizenship. Retrieved from http://www.europarl.europa.eu/igc1996/fiches/fiche10 en.htm.

Faist, T., Gerdes, J., \& Rieple, B. (2004). Dual citizenship as a path-dependent process. International Migration Review, 38(3), 913-944.

FitzGerald, D. (2008). Citizenship à la carte (Global Migration and Transnational Politics, Working Paper No. 3). Center for Global Studies. George Mason University. Retrieved from https:/www.gmu.edu/centers/globalstudies/publications/ gmtpwp/gmtp_wp_3.pdf.

Fransman, L. (1998). British nationality law. London et al: Butterworths.

Goldsmith, P. (2008). Citizenship: Our common bond. London: Ministry of Justice.

Gordon, S.M. (2007). Integrating Immigrants: Morality and Loyalty in US Naturalization Practice. Citizenship Studies 11(4):367382.

Groenendijk, K. (2006). The status of quasi-citizenship in EU member states: Why some states have 'almost-citizens'. In K. Groenendijk, R. Bauböck, E. Ersbøll, \& H. Waldrauch (Eds.), Acquisition and loss of nationality, (vol. 1, pp. 411-430). Amsterdam: Amsterdam University Press. 
Hammar, T. (1990). Democracy and the nation state: aliens, denizens and citizens in a world of international migration. Aldershot: Avebury.

Hansen, R. (2000). Citizenship and immigration in postwar Britain: The institutional foundations of a multicultural nation. Oxford: Oxford University Press.

High-level Committee on the Indian Diaspora (2002). Report on the Indian diaspora. New Delhi: Ministry of External Affairs, Government of India.

Immigration Law Practioners' Association (ILPA). 2001. Submission to Lord Goldsmith for the Citizenship Review: The Different Categories of British Nationality.

Jones-Correa, M. (2001) Under Two Flags: Dual Nationality in Latin America and Its Consequences for Naturalization in the United States. International Migration Review 35(4):997-1029.

Joppke, C. (2010). The inevitable lightening of citizenship. European Journal of Sociology, 51(1), 9-32.

Knott, E. (2017). Quasi-citizenship as a category of practice: Analyzing engagement with Russia's compatriot policy in Crimea. Citizenship Studies, 21(1), 116-135.

Kochenov, D. (2013). The essence of European citizenship emerging from the last ten years of academic debate: Beyond the cherry blossoms and the moon? International and Comparative Law Quarterly, 62(1), 97-136.

Maas, W. (2007). Creating European citizens. Lanham: Rowman \& Littlefield.

Maas, W. (2017). Multilevel citizenship. In A. Shachar, R. Bauböck, I. Bloemraad, \& M. Vink (Eds.), The Oxford handbook of citizenship, (pp. 644-668). Oxford: Oxford University Press.

Naujoks, D. (2010). India and its diaspora. Changing research and policy paradigms. In D. Thränhardt, \& M. Bommes (Eds.), National Paradigms of migration research, (pp. 269-300). Göttingen: V\&R Unipress.

Naujoks, D. (2013). Migration, citizenship and development. Diasporic Membership Policies and Overseas Indians in the United States. New Delhi: Oxford University Press.

Naujoks, D. (2015). The securitization of dual citizenship. National security concerns and the making of the overseas citizenship of India. Diaspora Studies, 8(1), 18-36.

Naujoks, D. (2018). Paradigms, policies and patterns of Indian diaspora investments. In R. S. Hegde, \& A. K. Sahoo (Eds.), Routledge handbook of the Indian diaspora, (pp. 90-103). Milton Park and New York: Routledge.

O'Keefe, D. (1994). Union Citizenship. In D. O'Keefe \& Patrick Twomey (Eds), Legal Issues of the Maastricht Treaty, (pp. 87-107). London: Chancery Wiley.

Pedroza, P. (2019). Citizenship beyond nationality Immigrants' right to vote across the world. Philadelphia: University of Pennsyvania Press.

Sahni, N. (2009). Economic Citizenship in India: A Socio-Legal Comparison of Two Cases. (Heidelberg papers in south Asian and comparative politics, Working Paper No. 46). Heidelberg: University of Heidelberg.

Sarhadi Raj, D. (2015). The overseas citizen of India and emigrant infrastructure: Tracing the deterritorializations of diaspora strategies. Geoforum, 59, 159-168.

Shachar, A., Bauböck, R., Bloemraad, I., \& Vink, M. (Eds.) (2017). The Oxford handbook of citizenship. Oxford: Oxford University Press.

Smith, R. M. (2003). Stories of Peoplehood: The Politics and Morals of Political Membership. Cambridge: Cambridge University Press.

Smith, R. (2017). Citizenship and membership duties toward quasi-citizens. In A. Shachar, R. Bauböck, I. Bloemraad, \& M. Vink (Eds.), The Oxford handbook of citizenship, (pp. 817-837). Oxford: Oxford University Press.

Soysal, Y. (1994). The limits of citizenship. Chicago: University of Chicago Press.

Spiro, P. J. (2016). At home in two countries: The past and future of dual citizenship. Ithaca: Cornell University Press.

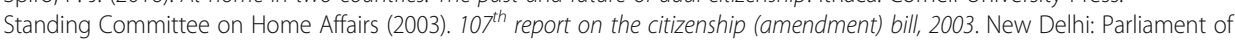
India, Rajya Sabha.

Thränhardt, D. (2008). Einbürgerung. Rahmenbedingungen, Motive und Perspektiven des Erwerbs der deutschen Staatsangehörigkeit. Bonn: Friedrich Ebert Foundation.

Turack, D. C. (1968). The Scandinavian passport union. Nordic Journal of International Law, 38(1), 171-118.

U.K. Home Office (1977). British nationality law: Discussion of possible changes. Green Paper. London: Her Majesty's Stationary Office.

U.K. Home Office (1980). British nationality law. Outline of proposed legislation. White paper. London: Her Majesty's stationary office.

Van Eijken, H. (2010). European citizenship and the competence of member states to grant and to withdraw the nationality of their nationals. Merkourios, 27(72) (Case Note, 65-69).

Weiler. J.H.H. (1996). European Citizenship and Human Rights. In A.E. Kellermann, B. de Witte, D. M. Curtin, \& J.A. Winter (Eds.), Reforming the Treaty on European Union: The Legal Debate (pp. 57-86). The Hague: Kluwer.

Wiener, A. (2011). European Citizenship. Academic Foresights 2. Retrieved from http://www.academic-foresights.com/ European_Citizenship.html.

Xavier, C. (2011). Experimenting with Diasporic incorporation: The overseas citizenship of India. Nationalism and Ethnic Politics, $17(1), 34-53$.

Yasar, R. (2017). Trajectories of emigrant quasi-citizenship: A comparative study of Mexico and Turkey. Comparative Migration Studies, 5. https://doi.org/10.1186/s40878-017-0061-3.

Yakut, B. (2010). The ECJ Case Law Concerning Articles 17 and 18 of the EC Treaty and the Subsequent Effect on the Right to Move Freely. Cilt: 9, No 1 (Yıl, 2010), pp. 147-164. Ankara Avrupa Çalışmaları Dergisi. Retrieved from http://www.readcube. com/articles/10.1501\%2FAvraras_0000000141.

\section{Publisher's Note}

Springer Nature remains neutral with regard to jurisdictional claims in published maps and institutional affiliations. 